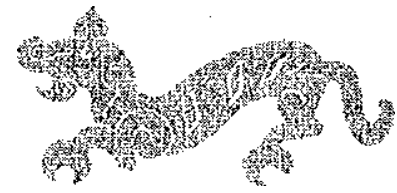

Janusz Kowalski

\section{POWSTANIE I ROZWÓJ CYWILIZACJI CHIŃSKIEJ}

\section{Część I}

Mimo znacznego postępu badań nad kulturą Chin oraz jej wkładem w uformowanie współczesnej cywilizacji technicznej, nierozstrzygniętym pozostaje spór o przebieg procesu dziejowego w tym regionie świata. Dyskusje ogniskowały się przez lata głównie wokół kwestii periodyzacji historii Azji Wschodniej i jej zgodności, albo odmienności, z europejskimi schematami rozwoju formacji społeczno-ekonomicznych, jak też przyczyn „zapóźnienia" społeczno-gospodarczego. Problemy z osiągnięciem konsensusu są w dużej mierze rezultatem stanu badań. Nie bez znaczenia wydaje się być również dominacja europocentrycznej perspektywy historiozoficznej. Historia Chin najlepiej jest znana w Chinach, a historia Zachodu w Europie, co tworzy odmienne punkty widzenia na rozwój cywilizacji i znaczenia Azji Wschodniej w tym procesie. Opracowania historii powszechnej pozostają jak na razie domeną naszego kręgu kulturowego, czego oczywistą konsekwencją jest przyjmowanie jej za wzorzec i miarę dziejów powszechnych. Nietrudno przy tym dostrzec, że rozróżnienie Wschodu i Zachodu jako przeciwstawnych sobie wzorców kultury ma swoje korzenie jeszcze $w$ historiozofii greckiej, $\mathrm{z}$ jej opiniami na temat wschodnich „despotii" ukształtowanymi przez Herodota, Tukidydesa, Platona i Arystotelesa, odnośnie Persji, rozciągniętych następnie, dzięki „immobilności" historyków zachodnich, jako kalka pojęciowa, na pozostałe kultury poza europejskie ${ }^{1}$.
Przykładem współczesnym, stanowiska podkreślającego różnice w poziomie rozwoju Europy i krajów Wschodu, upatrującego ich przyczyn już u zarania cywilizacji, jest syntetyczna praca F. Braudela, w której wysuwa tezę o „kulturowej immobilności" cywilizacji Dalekiego Wschodu. Konstatuje on, że:

niewątpliwie to w czasach prehistorycznych, na początku pierwszych cywilizacji, karty zostały rozdane. Cywilizacje Dalekiego Wschodu były Tymi, które bardzo szybko osiagneły niezwykłą dojrzałość, ale w zamian za to wiele swoich kluczowych struktur uczyniły nieomal nieprzenikliwymi dla zmian. Dało im to zadziwiającą jednolitość spójność. Ale spowodowało jednocześnie, że niezwykle trudno było im adoptować nowe idee i rozwiązania. Mogło to wywoływać wrażenie, jakby one systematycznie odrzucały ideę rozwoju i postępu ${ }^{2}$

W przypadku Chin głównymi przyczynami immobilności, w przekonaniu Braudela, było powstanie silnej, scentralizowanej biurokracji, kompleksu wierzeń religijnych $\mathrm{z}$ buddyzmem, taoizmem, a $\mathrm{W}$ szczególności $\mathrm{z}$ konfucjanizmem, będącym podstawą ideologii władzy cesarskiej. Silne więzi ekonomiczne i społeczne oparte na kulcie przodków oraz systemie rodowym powodowały, że raz ukształtowany wzorzec, mimo licznych kryzysów, odtwarzał sie ponownie w rytmie zmian dynastii dochodzacych do władzy skutkiem rewolt chłopskich lub najazdów koczowników z północy.

Również J. K. Fairbank, uważa, że źródeł nowożytnego zapóźnienia Chin należy poszukiwać już u zarania tej cywilizacji. Pisze on:

Przedwczesny rozwój Chin, jak się obecnie uważa, nie ograniczał się do sztuki

i techniki. W starożytnych Chinach pojawiło się autokratyczne, według wszelkich definicji, państwo z licznymi instytucjami administracyjnymi, archiwami, doborem urzędników według kwalifikacji ustalanych na podstawie egzaminów, centralną kontrolą nad gospodarką, społeczeństwem, literaturą i myślą. Ta chińska autokracja zapowiadała powstanie nowożytnych, absolutystycznych państw w XVII-wiecznej Europie. Nasz repertuar pojęć z zakresu nauk społecznych, który wywodzi się z pluralistycznego doświadczenia Zachodu, wydaje się nadal nie wystarczający, by objąć to wczesne chińskie osiągnięcie cywilizacyjne.

Jeżeli chcemy zrozumieć czynniki społeczne i ludzkie, które przyczyniły się do tego, że w czasach nowożytnych Chiny pozostały w tyle za Zachodem, musimy bliżej przyjrzeć się ich prehistorii, gospodarce ryżowej, systemowi rodzinnemu, najeźdźcam z tak zwanej Azji Wewnętrznej, myśli klasycznej i wielu innym cechom owej rozwiniętej cywilizacji, a następnie stwierdzić, jaką rolę mogły one w tym procesie odegrać

F. Braudel, A history of ciuilisation, London 1994

K. J. Fairbank, Historia Chin, nowe spojrzenie, Gdańsk 1996, s. 11 
Poglądy Braudela i Fairbanka korespondują z wcześniejszymi teoriami majacymi poważny wpływ na kształtowanie się poglądów odnośnie specyfiki powstania i rozwoju cywilizacji chińskiej — „azjatyckiego" sposobu produkcji K. Marksa oraz, będącej jej swoistą kontynuacją, teorii społeczności hydraulicznych K. Wittfogla.

Ukazanie się w 1957 r. pracy K. Wittfogla Orientat Despotism. A Comparative Study of htal Power dało nowy bodziec do dyskusji nad problematyką linearności rozwoju historycznego i przyczyn zróżnicowania tempa rozwoju kulturowego. W opinii Wittfogla przyczyna sprawcza powstania pierwszych państw i początków cywilizacji była konieczność nawadniania żyznych obszarów w dolinach rzecznych za pomocą systemów irygacyjnych, co przesądziło o rozwoju historycznym zamieszkujących te obszary ludów. Władza $\mathrm{w}$ tych społecznościach miała paternalistycznobiurokratyczny charakter, warunkowany patriarchalnym charakterem władzy u prymitywnych ludów rolniczych. Konsekwencją tego było kształtowanie sie ,despotii wschodnich", bedacych systemem władzy mogacym najskuteczniej w takich warunkach sprostać ogromowi zadań stojących przed państwem.

Wittfogel wyodrębniał właściwe, „klasyczne społeczeństwa hydrauliczne" (starożytne egipskie, mezopotamskie, chińskie, indyjskie, inkaskie itd.,), „marginalne społeczeństwa hydrauliczne", w których państwo w swej działalności gospodarczej koncentrowało się na budowaniu obiektów nie związanych z irygacją, ściaganiu podatków, obronności, itd. (za przykład podaje Bizancjum); wreszcie „submarginalne społeczeństwa hydrauliczne" (takie jak w Rosji i w Turcji), gdzie działalność państwa ograniczała się do zbierania podatków, podtrzymywania ładu wewnętrznego i obronności Jak widać, zwłaszcza na przykładzie „submarginalanych" państw, teoria "społeczeństwa hydraulicznego" jest potraktowana przez autora bardzo uniwersalistycznie.

Porównujac modele „generalnie niewolniczego", totalitarnego społeczeństwa „hydraulicznego" z modelami prekapitalistycznych społeczeństw europejskich posiadających instytucje demokratyczne (społeczeństwa antyczne i feudalne), Wittfogel stwierdzał istnienie dwóch dróg rozwoju cywilizacji: orientalną, gdzie element statyczny dominuje nad dynamicznym, oraz zachodnią, wykazującą znaczną dynamikę rozwojową. Wypowiada też pogląd, że ówczesny Związek Sowiecki i Chiny Ludowe stanowia kontynuację pierwszej drogi rozwoju, a przedłużeniem drugiej linii sa zachodnie społeczeństwa kapitalistyczne ${ }^{4}$

${ }^{4}$ K. Wittfogel, Oriental despotism, New Haven 1957.
Książka Wittfogla spotkało się z głośnym odzewem w świecie naukowym. Przewage zyskały głosy krytyczne. Sprzeciw uczonych - niemarksisławskich, budziło, między innymi, trywialne przeciwstawianie cywilizacj zachodniej - cywilizacji wschodniej, przywiązywanie nadmiernej wagi do irygacji jako czynnika sprawczego powstawania wschodnich despotii, ukazywanie tych państw jako struktur statycznych, bez uwzględniania ich okresowych ewolucji ku feudalizmowi, jednostronne ujmowanie zależności orientalnej biurokracji od despoty oraz demonizowanie roli biurokracji w historii. Zastrzeżenia budziło również wiązanie genezy orientalnych despotii ze świadomym działaniem archaicznych społeczeństw pragnących za pomoca państwa zagospodarować swoje środowisko ${ }^{5}$.

Krytycy o orientacji marksistowskiej wytknęli Wittfoglowi szereg oczywistych błędów i mielizn teoretycznych, jak na przykład, przywiązywanie nadmiernej wagi do wpływu czynników geograficzno-klimatycznych i irygacji na powstawanie określonych ustrojów społecznych i typów państwo, waści. Jak stwierdził M. Shapiro:

Duża część jego okazałej budowli nieuzasadnionych twierdzeń, opiera się na kilku słowach użytych przez Marksa dotyczących przypuszczalnego „azjatyckiego sposobu produkcji", myśli, której Marks ani nie rozwijał, ani do której nie wracał po naukowych badaniach starożytności przeprowadzonych przez Morgana i Engelsa ${ }^{6}$.

W szczególności wykpiono i odrzucono hipotezę Wittfogla, sugerującą że swoistymi spadkobiercami linii rozwojowej „despotii orientalnych" stały się ZSRR i ChRL. Uznano je za niedopuszczalne w nauce spekulowanie. Dowodzono, że Marks nie miał dostatecznie wiarygodnego materiału, ażeby autorytatywnie wypowiedzieć się na temat klasy panujacej we wschodnich despotiach i wolał poprzestać na ogólnikowych określeniach.

Polemizując z Wittfoglem dowodzono, że prywatna własność ziemi i stosunki feudalne kształtowały się w również w krajach, gdzie rolnictwo bazowało na irygacji, takich jak Indie, Chiny, Cejlon czy Japonia. Zarzucano mu również, że pisząc o historii Rosji przecenia znaczenie mongolskich wpływów na restrykcyjność władzy państwowej na Rusi Moskiewskiej, przy jednoczesnym lekceważeniu wewnętrznych, społeczno-ekonomicznych czynników rozwoju tego kraju.

W Polsce dyskusja skupiała się głównie na problemach związanych z hipotezą K. Marksa o ,azjatyckim" sposobie produkcji. Wittfoglowi zarzucano aprioryczność jego tezy, że klasą panującą na przed-kolonialnym Wschodzie była biurokracja oraz pomniejszanie znaczenia drobnej szlach-

${ }^{5}$ A. Toynbee, recenzja: „K. Wittfogel, Oriental Despotism", The American Political Science Review. 1958, nr 1, s. 195-198.

${ }^{6}$ M. Shapiro, „Stages of social development, Marxism Today, 1962, nr 9, s. 285. 
ty, silnie związanej z aparatem władzy. Zwracano przy tym uwage na konieczność pogłębienia badań nad problematyką ,azjatyckiego" sposobu produkcji ${ }^{7}$.

Przebieg dyskusji nad teorią „społeczeństw hydraulicznych" i przypomnianej przy tej okazji koncepcji ,azjatyckiego" sposobu produkcji mia wyraźnie polityczne zabarwienie i często więcej uwagi poświęcano w niej egzegezie wypowiedzi Marksa i Engelsa niż analizie nowych, nagromadzonych w ciągu stulecia materiałów źródłowych. Dyskusja ta, mimo ideologicznego tła sporu, przyczyniła sie jednak do znacznego ożywienia badań źródłowych społeczeństw azjatyckich, gdyż wykazała, że bez nich rozstrzygnięcie spornych kwestii jest niemożliwe.

Wspólna cechą teorii typu ,azjatyckiego" sposobu produkcji, społeczeństwa hydraulicznego, czy kulturowej immobilności, jest determinizm mający charakter wręcz fatalizmu historycznego. Zastrzeżenia wzbudza zastosowanie jednej kategorii pojęciowej dla zobrazowania procesu ciągłego rozwoju kulturowego, obejmującego — w przypadku Chin — okres sięgający początków neolitu, oraz blisko cztery tysiące lat historii pisanej, podczas gdy tylko dla dwóch ostatnich tysiącleci historii Europy używa się co najmniej pięciu kategorii opisujących odmienne etapy rozwoju społecznoekonomicznego. Cechą wspólną tych koncepcji jest również arbitralne przyjęcie za punkt wyjścia do porównywania stanu interesujących nas cywilizacji okresu przełomu XIX i XX wieku. Takie podejście w sposób oczywisty jest ahistoryczne, Zakładając zaś, że istniejący trend przesuwania się gospodarczego „środka ciężkości" z rejonu Atlantyku ku Pacyfikowi utrzyma się, to już w ciągu najbliższego półwiecza może dojść do zniwelowania istniejącej przewagi gospodarczej Zachodu, tak jak to jest już faktem w przypadku Japonii. Dlatego też być może jeszcze bardziej istotnym mankamentem tych teorii jest przyjęcie milczącego założenia (przy jednocześnie nieokreślonym horyzoncie czasowym porównywanych zjawisk), że raz zainicjowany w jakimś kierunku proces dziejowy powinien przebiegać następnie nie dość, że deterministycznie, to jeszcze w stałym tempie.

Zasadność pytania o istnienie odmiennych dróg rozwoju kulturowego, a w szczególności istnienie „azjatyckiej" specyfiki w tym zakresie, można rozstrzygnąć wyłącznie opierając się na materiałach faktograficznych. Przed przystąpieniem do dalszych rozważań istotne jest zdefiniowanie pojęcie cywilizacji w szerszym kontekście kulturowym, tym bardziej, że termin ten sprawia sporo kłopotów, szczególnie przy porównywaniu odmiennych cywilizacji. Stąd też, częściej korzysta się z definicji państwa,

1988 , s. 38 pojmowanego jako niezależna jednostka polityczna, zawierajaca w sobie mniejsze społeczności i ich terytoria z centralnym rządem władnym zbierać od ludności podatki, organizować roboty publiczne, prowadzić wojny i stanowić oraz egzekwować prawo. Istnienie państwa zakłada występowanie społecznej stratyfikacji, różnic $\mathrm{w}$ dostępie do dóbr i władzy, jak też zróżnicowanie zamożności wynikające $\mathrm{z}$ podziału pracy. To ostatnie oznacza, że część społeczeństwa korzysta z nadwyżek w produkcji żywności stając się „pełnoetatowymi" rzemieślnikami, handlarzami, kapłanami czy rządzącymi. U zarania państwowości religia była najczęściej ściśle połączona z państwem i władzą nadając im jednoznacznie sakralny charakter ${ }^{8}$

Koncepcja cywilizacji ma często wiele elementów wspólnych $\mathrm{z}$ definicją państwa. Ale też pojęciu cywilizacji przypisuje sie szersze znaczenie, w szczególności zakłada istnienie pisma, systemów filozoficznych oraz nie ograniczenia zasięgu występowania do terytorium pojedynczych państw. Prawdopodobnie najbardziej znana definicją cywilizacji jest zaproponowana przez V G. Childa lista dziesięciu kryteriów będących jej wyznacznikami. Zgodnie z nimi o istnieniu cywilizacji świadczy współwystępowanie takich elementów jak:

1. centra miejskie (od 7 do 20 tysięcy mieszkańców);

2. specjaliści zatrudnieni poza rolnictwem;

3. występowanie elit kreujących przywódców religijnych, cywilnych i militarnych;

4. wytwarzanie przez rolników nadwyżki żywności rozdysponowywanej przez władze;

5. monumentalne budowle publiczne symbolizujące koncentrację władzy;

6. używanie liczb i pisma;

7. znajomość arytmetyki, geometrii i astronomii;

8. wyrafinowana sztuka;

9. handel na duże odległości (ponad lokalny);

10. zinstytucjonalizowane formy organizacji politycznej — państwa ${ }^{9}$.

$\mathrm{Z}$ powyższym zestawem cech mamy po raz pierwszy do czynienia $\mathrm{w}$ Sumerze około 3200 r. p.n.e. i wkrótce potem w dolinie Nilu. W przypadku Indii początki tak rozumianej cywilizacji sięgają około roku 2200

BBliżej na ten temat patrz: R. L. Carneiro, „The theory of the origin of the stałe", Science, 1970, nr 169, s. 733-738; K. V. Flannery, "The cultural evolution of civilizations", The Annual Reuiew of Ecology and Systematics, 1972, nr 3, s. 399-425. $9 \mathrm{~V}$ G. Childe, „The urban revolution", w: The rise and fali of civilization. Modern
archeological approaches to Ancient cultures. Selected readings, red. J. A. Sabloff, C. C. Lamberg-Karlowski, Manio Park 1974, s. 6-14. 
p.n.e., podobnie jak w Chinach. W Meksyku i Peru analogiczne zjawiska datowane są na około 300 r. p.n.e."'. Uderzający jest fakt, że społeczeństwa wczesnych cywilizacji były często do siebie podobne. Piramidy egipskie są porównywane $\mathrm{z}$ piramidalnymi świątyniami Majów, a bogate pochówki władców Ur w Mezopotamii, zawierające wozy i liczne ofiary ludzkie, przywodzą na myśl groby pierwszych władców Chin w Anyangu. Tego rodzaju analogie zaowocowały w początkach naszego stulecia wieloma pomysłowymi teoriami, w których starano się wykazywać, że wszystkie cywilizacje miały wspólne źródło pochodzenia.

Dla australijskiego etnologa, G. E. Smitha (1871-1937), był nim Egipt i stąd właśnie „dzieci słońca" przekazywały rozwiązania techniczne i idee cywilizacji nawet do odległych zakątków ziemi, łącznie z Ameryką, tworząc „heliolityczne" kultury z megalitami i kultem słońca. Inni autorzy, podobne znaczenie przypisywali cywilizacji Bumeru. Również współcześnie podejmowane są próby udowodnienia prawdziwości teorii dyfuzjonistycznych. Szczególnym tego przykładem jest działalność Thora Heyerdahla, który wybudował statek z trzciny, wzorowany na staroegipskich, i przepłyną taka jednostka przez Atlantyk. Wyprawy Heyerdahla i jego naśladowców udowodniły możliwość podróży transoceanicznych już w okresie rozwoju wczesnych cywilizacji $\mathrm{z}$ zaczątkowymi ledwo technikami nawigacji $\mathrm{i}$ budowy statków".

Teorie dyfuzjonistyczne nie są zatem pozbawione podstaw, co wykazała chociażby pierwsza wyprawa Heyerdahla na tratwie "Kon Tiki", w odniesieniu do możliwości zasiedlenia wysp Pacyfiku przez prekolumbijskich mieszkańców Ameryki. Problem polega jednak nie tylko na udowodnieniu, że kontakty takie mogły mieć miejsce. Nie ulega wątpliwości, że powstanie państw w Sumerze przyśpieszyło proces formowania państwowości u okolicznych plemion, zmusiwszy je do rozwijania bardziej scentralizowanych struktur zarzadzania dla przetrwania $\mathrm{w}$ konfrontacji $\mathrm{z}$ silniejszym przeciwnikiem.

- Z pewnością miało to jednak ograniczony zasięg, gdyż poziom rozwoju techniki wojennej i gospodarki, umożliwiających dalekosiężne wyprawy, został osiągnięty w Mezopotamii dopiero za czasów Sargona, około tysiąca lat po powstaniu pierwszych państw, a i w tym przypadku działania wojenne ograniczały się do obszaru Międzyrzecza. Największą słabością teorii dyfuzjonistycznych jest, przy braku bezpośrednich świadectw kontaktu, trudność z uzasadnieniem dlaczego to, co zostało dokonane przez jedne społeczności nie może być osiągnięte niezależnie przez inne. Impli-

${ }^{10}$ M. Harris, Dur bind, New York 1990, s. 467-473.

${ }^{11}$ Szerzej na ten temat patrz T. Heyerdal, Early man and the ocean: The beginning of navigation and seaborne civilizations, London 1979. kuje to również istnienie sekwencji rozwoju kulturowego naśladowanego następnie przez coraz odleglejsze społeczności

Zwolennicy dyfuzjonizmu argumentowali, że tak skomplikowana sekwencja splecionych ze sobą zdarzeń koniecznych dla zaistnienia cywilizacji mogła zajść tylko jeden raz w historii człowieka. W podobny sposób traktowano narodziny metalurgii, jednakże i tu brak jest dostatecznego uzasadnienia dla takiego podejścia.

W przypadku cywilizacji Chin starano się, zgodnie $\mathrm{z}$ ta teorią, udowodnić, że u jej podłoża legły zapożyczenia z obszaru Bliskiego Wschodu. G. Anderson, jeden z prekursorów badań archeologicznych w dolinie Rzeki Żółtej w okresie międzywojennym, wysunął tezę o zachodnim pochodzeniu rolnictwa w Chinach. Głównym argumentem na poparcie teorii dyfuzji była cechy zdobnictwa ceramiki Yangshao, zbieżne z ceramika kultury Tripolie znad Morza Czarnego ${ }^{12}$.

W ciągu ostatnich 20-30 lat koncepcja dyfuzjonistyczna, zakładająca, że większość najważniejszych wynalazków została dokonana tylko raz, a następnie rozprzestrzeniła się poprzez kontakty między ludźmi na różne obszary, nie cieszyła się popularnością. W szczególności poglądy hyperdyfuzjonistów, którzy upatrywali początek wszystkich cywilizacji w Egipcie bądź w Sumerze, dziś wyglądają absurdalnie. Nie poświadczają tego znaleziska archeologiczne, a obalaja to wrecz liczne świadectwa lokalnych procesów rozwojowych. Oparcie chronologii różnych obszarów na nowoczesnych metodach datowania, opartych w szczególności na pomiarze zawartości promieniotwórczego izotopu węgla C-14 (o czasie połowicznego rozpadu wynoszącym ok. 5500 lat) w znajdowanych przedmiotach pochodzenia organicznego, tak zwane datowanie radiowęglowe, pozwalało, w szczególności po ich kalibracji, na przeprowadzanie porównań w oparciu o chronologię bezwzględną, .a nie tylko, jak w minionym okresie, relatywną, można nie tylko odtworzyć chronologię lokalną typu starsze-młodsze ale datować $\mathrm{z}$ dokładnością rzedu \pm 150 lat. Oczywiście, można nadal twierdzić jak czyni to paru dyfuzjonistów - że kultura Egiptu miała znaczny wpływ na kulturę Ameryki Środkowej. Jednak wedle opinii większości badaczy, ludność Ameryki samodzielnie rozwinęła gospodarkę rolną, tworząc podstawy dla cywilizacji mezoamerykańskiej ${ }^{13}$.

Chronologicznie, palma pierwszeństwa $\mathrm{w}$ tworzeniu cywilizacji należy do Sumerów. Jednakże do oceny poczatku i rozwoju jakiejkolwiek cywilizacji nieodzowne jest poznanie warunków jej istnienia, a więc gospodarki, technologii, systemu społecznego, demografii, ideologii i wymiany han-

${ }^{12}$ G. Anderson, Children of the Yellow Earth, London 1934

${ }^{13}$ R. S. MacNeish, „Ancient Mesoamerican Civilisałion", Science, vol. 143, 1964, s. 531-537. 
dlowej. Zadaniem archeologicznych badań procesów oddziaływań interkulturowych jest odkrywanie tych czynników, które ułatwiały wymianę zarówno w aspekcie warunków lokalnych, jak społecznych konsekwencji handlu zewnętrznego. Samo tylko analizowanie kontaktów ze starszymi cywilizacjami w kategoriach domniemanych wpływów — to za mało.

Nie można też stosować podziału cywilizacji na „pierwotne" i „wtórne", proponowanego przez M. Frieda ${ }^{14}$. Niewątpliwie, różne społeczeństwa utrzymywały pomiędzy sobą kontakty i z pewnością fakt ów w sposób znaczący wpływał na ich kultury. Jednak jest to zadanie dla archeologów, którzy musza najpierw udokumentować istnienie takich kontaktów, a dopiero potem badać ich znaczenie. Wstępny podział na cywilizacje „pierwotne" i „wtórne" jest zbyt płynny.

Lepsze efekty daje badanie warunków istniejących na pewnym obszarze przed powstaniem złożonego systemu społecznego, a następnie śledzenie rozwoju od etapu pierwszych rolników poprzez społeczeństwo klasowe, wykazujace pewien stopień krystalizacji władzy, aż do powstania państwa. Aktualne badania proponuja nowe sposoby podejścia do tego problemu. Ewolucja społeczna nie jest procesem jednolitym, a społeczeństwo klasowe nie musi rozwinać sie w społeczeństwo o charakterze państwowym. Jednak żadna cywilizacja nie rozwinęła się bez solidnych podstaw zaopatrzenia $\mathrm{w}$ żywność, jak też bez zróżnicowania społecznego pod względem zamożności i prestiżu ${ }^{15}$.

Równie złożonym problemem co powstanie cywilizacji sa stosunkowo częste przypadki ich załamania i upadku. Dobrze znany jest fakt zaniku cywilizacji mykeńskiej w Grecji około 1100 lat p.n.e. Uderzająco podobny proces obserwujemy śledząc raptowny upadek państwa Majów około 900 roku n.e., a także innych społeczeństw wczesnopaństwowych, między innymi, w dolinie Indusu około 1900 roku p.n.e.

Niektóre wczesne uogólnienia dotyczące powstania i upadku cywilizacji, jak na przykład brytyjskiego historyka A. J. Toynbee (1889-1975) nie tyle wyjaśniały ich przyczyny, co zwracały uwage na istnienie takiego zjawiska. Inne podkreślały znaczenie tylko jednego czynnika. Wspomniany już wcześniej K. Wittfogel przykładał dużą wagę do intensyfikacji produkcji żywności poprzez wprowadzenie do rolnictwa irygacji, co miało mieć z kolei decydujący wpływ na wzmocnienie i centralizację władzy.

Gordon Childe, twórca pojęcia rewolucji neolitycznej, był pierwszym archeologiem, który drogą systematycznych studiów zebrał i opublikował dane dotyczących początków cywilizacji w pracy Najdawniejszy

${ }^{14}$ M. H. Fried, The evolution of political society: An essay in political anthropology, New York 1967.

${ }^{15}$ J. E. Pfeiffer, Emergence of society, New York, 1977, ss. 83-104. wschód (1928). Zarys swoich poglądów zawarł w następnych, ciekawie i po mistrzowsku napisanych pracach: Człowiek stworzyt sam siebie (1937) $i$ Rewolucja miejska (1950). Kolejną ciekawą propozycją były koncepcje amerykańskiego antropologa Roberta Adamsa, zawarte w jego wykładach o L. H. Morganie i wydane w roku 1965: Ewolucja społeczeństwa miejskiego. W pracy tej po raz pierwszy został systematycznie porównany rozwój cywilizacji na dwóch różnych obszarach, mianowicie wczesnej Mezopotamii i przed hiszpańskiego Meksyku ${ }^{16}$.

Ojcem-założycielem antropologii ewolucyjnej był Morgan (1818-1881). Jego Spoleczeństwo pierwotne (1877) miało poważny wpływ na Karola Marksa, który kładł nacisk na stosunki pomiędzy strukturami gospodarczymi i społecznymi w społeczeństwach przedkapitalistycznych. Zawarte w koncepcji Marksa pojęcia „sposobu produkcji" i „stosunków produkcji" wpłynęły na koncepcje Childe'a i bezpośrednio, lub pośrednio, oddziaływały na postawę większości jego uczniów. Również niektórzy inni badacze powracali do oryginalnych prac Marksa.

Obiecującą metodą jest rozpatrywanie społeczeństw „wczesnopaństwowych" nie z punktu widzenia intensyfikacji produkcji żywności, co podkreślał Wittfogel, lecz raczej jako organizacji o sprawnym systemie informacyjnym, który ułatwia rozwój administracji centralnej. Ta metoda została z powodzeniem wykorzystana przez K. Flannery'ego ${ }^{17}$ oraz H. Wrighta $\mathrm{w}$ badaniach nad hierarchią osad $\mathrm{w}$ okresie formowania się pierwszego państwa na terenie Iranu ${ }^{18}$

Dzisiejsze prace wykopaliskowe sa coraz silniej zorientowane na pewne określone cole - archeolodzy podejmują swe badania, aby uzyskać odpowiedź na pytania wynikające $\mathrm{z}$ ogólniejszych teoretycznych rozważań. Większość ostatnich badań ma charakter interdyscyplinarny, a studia nad powstaniem wczesnych społeczeństw prowadzone są obecnie na całym świecie i nasza wiedza na temat natury i początków cywilizacji konsekwentnie się powiększa. Przez ponad stulecie, aż do lat pięćdziesiątych naszego wieku, studia nad początkami cywilizacji koncentrowały się na badaniach archeologicznych wielkich ośrodków świata starożytnego oraz publikowaniem drobiazgowych opisów znalezisk. Dzięki temu obraz egzystencji wielu wczesnych społeczeństw stopniowo nabierał wyraźniejszych kształtów.

${ }^{16}$ R. M. Adama, Evolution of urban society, London 1965.

K. Flannery, „The cultural evolution of civilisations", The Annual Review of Ecology and Systematics, vol. 3, 1972, s. 399-425.

H. T. Wright, ,Recent Research on the Origin of the State", Annual Review of Anthropology, 1997, s. 379-397. 
Dokonania wielkich pionierów - Austena H. Layarda (1817-1894) i Leonarda Woolleya (1880-1960) w Mezopotamii, a Arthura Evansa (18511941) na Krecie - czy też pierwsze odkrycia prekolumbijskich ośrodków Ameryki, nie tylko położyły trwały fundament pod nasze rozumienie początków cywilizacji, ale też po raz pierwszy pozwoliły uzmysłowić nam sobie różnorodność cywilizacji. Nie bez znaczenia było również archeologiczne potwierdzenie istnienia, a czasami wręcz odkrycie, takich państw jak Hetytów, mieszkańców miast doliny Indusu, Olmeków czy Minojczyków, o których istnieniu niemal niczego nie wiedziano przed pionierskimi wykopaliskami z ubiegłego stulecia i początków XX w.

We współczesnych pracach dotyczących niektórych obszarów, punkt ciężkości przesuwa się stopniowo $\mathrm{z}$ odkrywania i rekonstruowania na rozumienie i wyjaśnianie. Systematyczne studia porównawcze wczesnych cywilizacji zyskały nowe podstawy. Podejmowane są konsekwentne próby rozwinięcia modeli heurystycznych, które proponowałyby rozwiązania problemu: jak i dlaczego poszczególne cywilizacje wyłoniły się w różnych czasach i w różnych rejonach globu. Podejście takie zdaje się wypierać proste odtwarzanie faktów związanych $\mathrm{z}$ narodzinami cywilizacji oraz poszukiwania pojedynczych czynników sprawczych, takich jak intensyfikacji produkcji żywności, rozwój technologii, presja demograficzna, czy też potrzeba organizacji będąca rezultatem współzawodniczenia o deficytowe dobra.

Sa to niewatpliwie istotne czynniki, ale każdy z nich z osobna nie jest wystarczającym wytłumaczeniem przyczyn tak złożonego procesu, jakim jest powstanie cywilizacji. Z punktu widzenia teorii systemów konieczne jest nie tylko znalezienie zespołu czynników sprawczych, ale również wykazanie ich wzajemnej relacji w całym procesie. Istnienie cywilizacji nie jest bowiem możliwe bez interakcji różnorodnych podsystemów. Dla przykładu: na podsystem rolniczy wpływa postęp technologiczny w wytwarzaniu narzędzi, a ten z kolei wynika z rozwoju produkcji w podsystemie kopalnictwa. Moga również nastapić negatywne interakcje. Na przykład, zwiększanie podatków ogranicza siłę nabywczą chłopów zmuszając ich do autarkii, co z kolei wpływa na obniżenie poziomu rzemiosła.

Również w przypadku Chin nasza wiedza o początkach tej cywilizacji wzrosła znacznie w ostatnich latach. Najnowsze badania archeologiczne stanowisk w dorzeczu rzeki Huanghe w Chinach Północnych potwierdziły znaczenie tego obszaru dla rozwoju cywilizacji chińskiej. Odkryto tam świadectwa istnienia społeczności typu neolitycznego. Społeczności te zamieszkiwały w wioskach i uprawiały dwie odmiany prosa już co najmniej 8.000 lat temu. Uprawa ryżu, zarówno odmiany długo jak i krótko ziarnistej, znana jest w Chinach południowych od co najmniej 7.000 lat. Wprawdzie dzikie odmiany prosa znane są zarówno w Azji Wschodniej jak
$1 \mathrm{w}$ Europie, to jednak na naszym kontynencie podstawą upraw była bardziej wydajna pszenica, która wprawdzie dotarła również do Chin, ale dopiero około 1300 r. p.n.e., czyli 6.000 lat po udomowieniu jej na obszarach Azji Zachodniej. Przejście od gospodarki przyswajalnej, myśliwsko-zbierackiej, do produkcyjnej, z uprawą roli i hodowla zwierząt, okazało się być bardzo złożonym zjawiskiem. Badania współczesne wykazały, że rolnictwo nie jest jednorazowym „wynalazkiem", który by się następnie rozprzestrzenił z jednego centrum na dalsze obszary, ale trwającym wiele tysięcy lat procesem zapoczątkowanym $\mathrm{w}$ kilku miejscach świata, niezależnie od siebie. Dopiero długotrwale przemiany ewolucyjne, będące swoistymi eksperymentami, trwającymi przez wiele pokoleń, doprowadzily do wynalezienia techniki upraw i hodowli z jednej strony, a do wyselekcjonowania nowych odmian roślin i zwierzą $-\mathrm{z}$ drugiej. Narodziny nowej gospodarki odbywały się na styku bezpośrednich oddziaływań człowiekśrodowisko, stąd wielkie znaczenie dla poznawania tego procesu mają nauki przyrodnicze ${ }^{19}$.

Jedna z metod dociekań nad początkami rolnictwa sa badania rozprzestrzenienia dzikich odmian roślin uprawnych. $\mathrm{Na}$ ich podstawie, prekursor tej dziedziny, N. I. Wawiłow wydzielił osiem światowych centrów rolniczych, na których obszarach dochodziło do wyselekcjonowania dzikich roślin przydatnych pod uprawe, i stą już jako uprawne rozprzestrzeniły się dalej. Jednym z takich centrów są Chiny, dla których Wawiłow wylicza 136 gatunków roślin uprawnych (na ogólną liczbę 666 dla całego świata) ${ }^{20}$. Czyni to Kraj 'Środka jednym z najważniejszych ośrodków „rewolucji neolitycznej", zwłaszcza przy uwzględnieniu faktu, że znaczna część Chin Południowych wchodzi w obręb centrum indo-malajskiego z dalszymi 196 gatunkami. regionu:

Współcześnie Li Huilin proponuje bardziej szczegółowy podział tego

1. Chiny Północne (od południowej Mandżurii przez dolinę Huanghe po pasmo Qinlingshan);

2. Chiny Południowe (na południe od Qinlingshan);

3. Azja Południowa-wschodnia (Birma, Tajlandia, Wietnam, Laos, Kambodża); 4. Wyspy Południowe (Półwysep Malajski i Archipelag Malajski) ${ }^{21}$

${ }^{19}$ Bliżej na ten temat patrz J. R. Harlan, „Agriculturał Origins: Centers and Noneentors", Science vol. 174, 1971 n, s. 468-474; D. Rindos, „Symbiosis, instability, and the onigins and spread of agriculture: A new model", Current Anthropology, Vol. 21, Na. 6, 1980, s. 751-772. ${ }^{20}$ I. Vavilov, ,The origin, variation, immunity, and breeding of eultivated plants", Chronicy Botanicy, $\mathrm{nr} 13,1949 / 51$.

${ }^{21} \mathrm{Li}$ Hui-lin, „The origin of cultivated plants in Southeast Asia", Economic Botany, nr 24 1970 
Podział ten dobrze oddaje zróżnicowanie tego obszaru, którego podstawą są czynniki klimatyczne. Chiny Północne leżą w strefie umiarkowanej z zimą przerywająca okres wegetacji (ujemne temperatury i opady śniegu), podczas gdy Chiny Południowe, z klimatem subtropikalnym i monsunami, zawsze mają temperatury dodatnie, umożliwiające całoroczną wegetację i wielokrotne plony. Aktualnie granica tych klimatów przebiega na wysokości pasma Qinlingshan (izoterma stycznia $\mathrm{O}^{\circ} \mathrm{C}$ ). W okresie optimum klimatycznego holocenu (8-4 tys. lat temu) granica ta mogła przebiegać bardziej na północ od obecnej.

Powyższe podziały, znajdują swoje odbicie również w materiałach archeologicznych. Badania terenowe nad neolitem, podjęte w latach dwudziestych naszego wieku, a kontynuowane $\mathrm{z}$ coraz większym rozmachem szczególnie $\mathrm{w}$ ostatnich dziesięcioleciach, doprowadziły do odkrycia trzech odrębnych ośrodków wczesnoneolitycznych.

Najbardziej na południe położony jest krąg kultury Dapenkeng i kultur jej pokrewnych z południowo-wschodniego wybrzeża Chin. Krąg ten pozostaje pod wyraźnym wpływem kultury hoabhińskiej (Indochiny). Pozostałości materialne sugeruja, że podstawa utrzymania było wykorzystywanie zasobów morza (stanowiska na śmietniskach muszlowych), a uzupełnieniem magla być uprawa roślin bulwiastych i korzeniowych.

Najistotniejsze znaczenie dla rozwoju rolnictwa i później całej cywilizacji chińskiej przypisuje się jednak dwu innym obszarom: dolinom wielkich rzek Huanghe i Yangzijiang.

Najlepiej i najwcześniej poznaną (odkrytą w 1920 r. przez Gunnara Andersona) jest wspomniana już wcześniej kultura Yangshao, zajmująca znaczne obszary dorzecza Huanghe. A więc na obszarze gdzie mieściły się centra trzech najwcześniejszych dynastii: legendarnej Xia, Shang i Zhou. Toteż nic dziwnego, że tutaj też skupił się główny wysiłek badawczy.

Stanowiska kultury Yangshao znajduja się w dużych i małych dolinach dorzecza Rzeki Żółtej, często na niskich, lessowych terasach wzdłuż brzegów rzek. Znaleziska z obszaru całej kultury wskazują na zróżnicowanie zarówno terytorialne, jak i chronologiczne. Odmienności te jednak dotyczą przede wszystkim zdobienia ceramiki, podczas gdy pozostałe elementy kultury materialnej są silnie zunifikowane. Dotyczy to zwłaszcza narzędzi związanych z uprawą ziemi, jak motyki, kamienie z wywiercanym otworem do kijów-kopaczek, gładzone ciosła i noże oraz żarna. Dobrym przykładem wyglądu osady kultury Yangshao jest stanowisko Ban-po, położone niedaleko Xianu, w większym skupisku osadniczym nad rzeką Chan.

Obszar zabudowań chroniony jest tu rowem, głębokim na $6 \mathrm{~m}$ i tyleż szerokim, otaczajacym obszar o powierzchni około 30 tys. $\mathrm{m}^{2}$. Odkopano na nim czterdzieści sześć chat i jeszcze większą liczbę zagród dla zwie rząt i dołów magazynowych. Domostwa, niewielkich rozmiarów, budowane najczęściej na planie koła o średnicy 3-5 m, ale również na założeniach prostokątnych i owalnych o zbliżonej wielkości, otaczały plac centralny z dużym domem wspólnotowym (wielkości $20 \times 12 \mathrm{~m}$ ). Poza rowem po stronie wschodniej, zlokalizowano zespół co najmniej sześciu pieców garncarskich (w jednym $\mathrm{z}$ nich pozostały naczynia, przygotowane do wypalenia). Z kolei, na północ od osady znajdowało się cmentarzysko z pochówkami ponad 130 osób dorosłych (szczątki dzieci palono i grzebano w urnach między chatami). Podobnie wygląda rozplanowanie stanowiska Jiangzhai, leżącego o $15 \mathrm{~km}$ na wschód od Banpo. Tu również cmentarzysko i piece garncarskie ulokowano poza obrębem rowu otaczającego część mieszkalną wioski ${ }^{22}$.

W kulturze Yangshao rośliny uprawiane były metodą kopieniaczożarową głównie takie jak: proso zwyczajne, włośnica ber oraz $\mathrm{z}$ roślin motylkowych — soja. Podstawowymi zwierzętami hodowlanymi były świnie i psy, o wiele rzadziej znajduje się resztki bydła i owiec czy kóz. Znaczny udział w diecie miało jednak w dalszym ciagu zbieractwo, myślistwo i rybołówstwo. Świadczą o tym liczne kości takich dzikich zwierząt jak koń, lampart, jeleń, jeleń wodny, dzikie bydło, nosorożec, antylopa i wiele pomniejszych gatunków. Do polowania używano łuków (liczne znaleziska grotów strzał) i oszczepów. W paru przypadkach znalezione kamienne kule do proc. O znaczeniu rybołówstwa świadczą harpuny, haczyki i gliniane oraz kamienne ciężarki do sieci. Motywy ryb często pojawiają się na ceramice, mogły też występować jako tatuaż o czym świadczy dekoracja ceramiki w formie ludzkiej twarzy tatuowanej w ryby (rys. 1.).

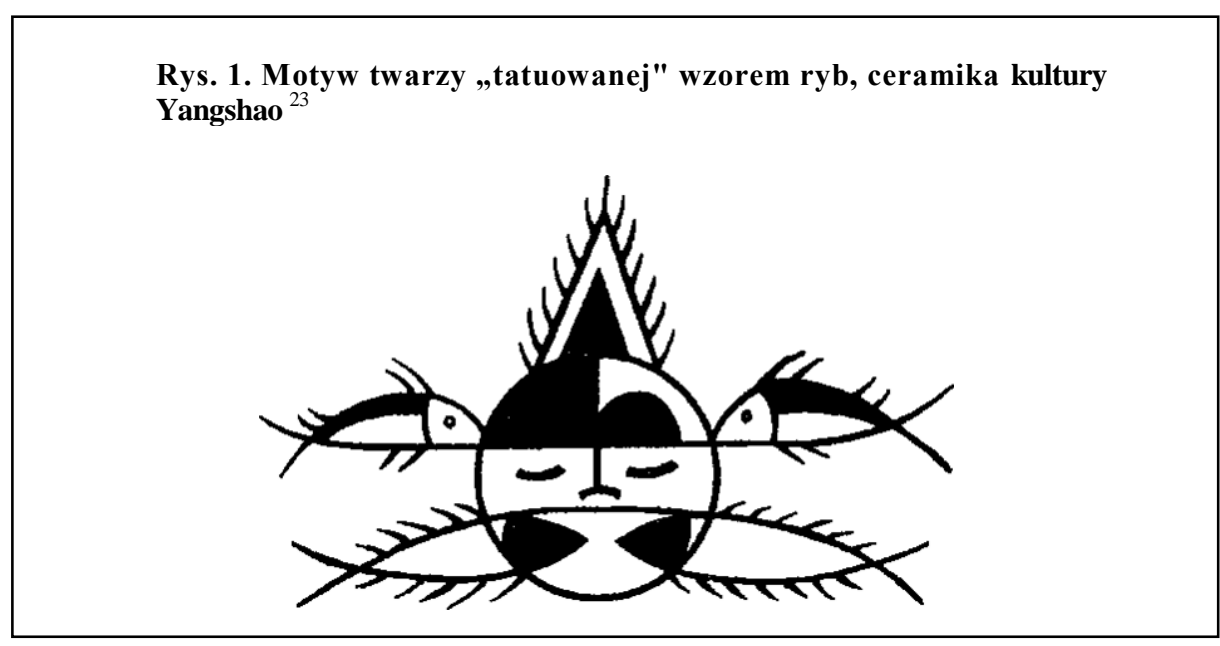

22 K. C. Chang, The Archaeology of Ancient China, London 1977, s. 93-132.

23 "Chinese Traditional Auspicious Paterns", chief editor Liu Zuding, Shanghai 1990, Shanghai Popular Science Press, s. 78. 
Ceramika była lepiona ręcznie, a czasami, zwłaszcza w późniejszych okresach, wykańczana przez obtaczanie. Zachowały się przybory służące do wyrobu i zdobienia ceramiki. Częste są kościane radełka, kamienne gładziki, rozcieracze do barwników i naczynka na farby. Ceramika Yangshao wykazuje duże walory artystyczne, przez co zajmuje poczesne miejsce w wielu znaczących kolekcjach sztuki na całym świecie ${ }^{24}$.

W 1951 roku odkryta trzecia kulture wczesnoneolityczną Chin, mianowicie Qingliangang. Występuje ona w dorzeczu Huanghe i w dolnym biegu Yangzijiang, jako poprzedzająca krąg kultur longshanoidalnych, wyznaczany przez charakterystyczną czarną ceramikę. Szczególne znaczenie tej kultury wynika ze znajdowania w jej obrębie świadectw uprawy ryżu.

Badania nad kulturą Qingliangang pozwoliły dokonać rozwarstwienia chronologicznego i terytorialnego. Znaczne różnice pomiędzy grupa leżaca na południe od Yangzijiang, a grupą północną wskazują, że możemy tu mieć do czynienia z dwiema odrębnymi kulturami, a nie tylko z różnicami wynikłymi z odmienności klimatyczno-środowiskowych. Do wspólnych cech można zaliczyć występowanie czerwonej ceramiki (czasami malowanej) i płaskich, z gładzonego kamienia wykonanych toporów o dużych otworach w centrum ostrza (oś rękojeści prostopadła do płaszczyzny ostrza, jak w motykach i ciosłach); ale zasób częstotliwość wystepowania poszczególnych wytworów jest w obu grupach odmienna. Istotne jest, że na północ od Yangzijiang nie stwierdzono uprawy ryżu. Dalsze badania niewątpliwie pomogą rozstrzygnąć liczne problemy; toteż tereny te badane są coraz intensywniej.

W wyniku prac prowadzonych w 1973 i 1977 r. odkryto stanowisko Hemudu (prowincja Zhejiang na południe od Yangzijiang, nad rzeka Yao) z najstarszym datowanymi metodą radiowęglową świadectwami uprawy ryżu. Odsłonięto tu cztery warstwy, z których najniższa datowana jest na początek V tysiąclecia p.n.e. Zestaw narzędzi oraz ziarna i plewy zarówno uprawnych, jak i dzikich odmian ryżu wskazują na wysoki już poziom techniki upraw. Szczególnym jej przekładem są kościane radlice soch, których znaleziono w najniższej warstwie ponad 70 kawałków. Wraz ze szczątkami bawołu wodnego wskazuje to na możliwość sprzężajnej uprawy pól zalewiskowych, a więc na znacznie wyższe zaawansowanie techniki upraw $\mathrm{w}$ porównaniu $\mathrm{z}$ technika żarowa $\mathrm{w}$ kulturze Yangshao. W kulturze Qingliangang, podobnie jak w innych kulturach wczesnoneolitycznych, duże znaczenie zachowało zbieractwo i myślistwo. W Hemudu znaleziono kości 50 gatunków zwierząt, w tym jeleni, nosorożców, słoni, małp i żółwi. Hodowano świnie i psy.

J. Kowalski, „Wczesnoneolityczne kultury dorzecza Huanghe i Yangzijiang", Orient, tom I, 1988 r., ss. $24-25$.
Ceramika z Hemudu jest słabo wypalona. Do jej wyrobu stosowano gline z domieszką traw i plew, co po zwęgleniu nadawało jej czarny kolor. W zdobieniu często występuje motyw świni; dekorowano też przez odciskanie sznura czy radełka. W Hemudu zachowały się liczne wyroby z kości i drewna (ornamentyka przedmiotów kościanych znajduje odbicie w wiele tysięcy la później, w grobowcach epoki Han $\mathrm{z}$ Mawangdui). Znaleziono również narzędzia do pozyskiwania włókien, wyrobu nici i tkactwa (czółenka, przycinacze, igły, przęśliki). Jak w przypadku Yangshao, tak i w tej kulturze nie wyjaśniona jest jej geneza ${ }^{25 "}$

Wspomniana już zbieżność ceramiki Yangshao i Tripolia, jak też znaczenie przypisywane Bliskiemu Wschodowi w procesie formowania kultur neolitycznych, dawały asumpt do szukania źródeł neolitu właśnie na zachodzie. Poglądy te głoszą i obecnie niektórzy europejscy uczeni, zwłaszcza w odniesieniu do neolitu Chin Północnych. Badania prowadzone w Tajlandii, Japonii, Wietnamie i w Chinach dowodzą jednak występowania w Azji Wschodniej społeczności, które mogły samodzielnie przejść od zbieractwa łowiectwa do uprawy i hodowli. Na przykład, z terenu Japonii znane sa najstarsze w świecie wyroby ceramiczne, datowane metoda C-14 na koniec XI tysiaclecia p.n.e. (kultura Jomon) ${ }^{26}$. Charakterystyczny dla tej ceramiki jest motyw odciśniętego sznura, taki sam sposób zdobienia występuje' w ceramice kultur wczesnoneolitycznych Chin i Azji Południowy-Wschodniej (kultura hoabhińska, będąca raczej kręgiem kulturowym, ma bardzo szeroki zasięg i znana jest z Indochin, Indonezji, a możliwe, że sięgała nawet do Australii.) świadczy to o niezwykle rozległym zasięgu kontaktów miedzy kulturami. Jest to również świadectwo istnienia odmiennej niż na Bliskim Wschodzie sekwencji kulturowej, w ramach której rolnictwo (tak zwany neolit preceramiczny) poprzedza. wynalezienie garncarstwa.

Dalszy postęp $\mathrm{w}$ badaniach terenowych powinien pozwolić na pełniejsze poznanie genezy kultur neolitycznych w Chinach. Wystepujace na jej obszarze horyzonty ceramiki sznurowej, a później kultur longshanoidalnych, świadczą o rozległych procesach unifikacyjnych i o tym, że kultury uczestniczące w tych procesach były otwarte na impulsy $\mathrm{z}$ zewnatrz. Należy podkreślić, że do przyjęcia modelu gospodarki wytwórczej, rolniczo-hodowlanej, nie wystarcza tylko samo przekazanie idei, muszą też istnieć odpowiednio rozwinięte społeczności, zdolne do przejęcia takiego modelu. Dlatego mimo braku pełniejszych danych, dotyczacych lokalnych kultur mezolitycznych schyłkowopaleolitycznych z obszaru Huanghe i Yangzijiang, powiązanie początków rolnictwa z wykorzystywaniem lokalnych

${ }^{25}$ ibid., s. 26.

${ }^{26}$ J. Tubielewicz, Historia Japonii, Warszawa, 1984, s. 14. 
roślin pod uprawy oraz rozprzestrzenianie się rolnictwa $\mathrm{z}$ tych obszarów na dalsze tereny (również $w$ kierunku zachodnim) pozwała przypuszczać, że początki neolitu w Chinach, mimo ich późniejszej niż na Bliskim Wschodzie metryki, wiążą się z rozwojem społeczności lokalnych ${ }^{27}$.

Wczesnoneolityczne społeczności Chin Północnych wykazuja małe zróżnicowanie zamożności wewnątrz grupy. Brak też jest praktycznie znamion, by wojny miały większe znaczenie. Pod koniec trwania kultury Yangshao osady zaczynają stopniowo przybierać charakter obronny. Proces ten nasila się w szczególności w kulturze Longshan (4600-3850 lat temu). W okresie tym obserwowany jest szybki wzrost produkcji rolnej połączonej ze wzrostem gęstości zaludnienia i większymi, bardziej stałym osadami. Znamienne są również świadectwa wzrastającego znaczenia podziału pracy, w tym używania koła garncarskiego do wyrobu naczyń, czy świadectwa istnienia warsztatów do obróbki jadeitu. Podział pracy sprzyja wzrostowi wydajności zarówno w wymiarze jakościowym jaki ilościowym $i$ jest zaliczany do jednego $z$ niezbędnych warunków powstania cywilizacji. Również nowym zjawiskiem jest coraz wyraźniejsze zróżnicowanie społeczne dostrzegalne w wyposażeniu pochówków. Kultura Longshan, najprawdopodobniej na skutek presji demograficznej, rozprzestrzeniła się na nowe obszary. $\mathrm{Na}$ jej bazie, prawdopodobnie na obszarze prowincji Henan, doszło do powstania pierwszego państwa chińskiego ${ }^{28}$

Pod koniec III tysiąclecia p.n.e. pojawia się coraz więcej świadectw wzrastania znaczenia wojny. Pojawiaja się kompleksy miejskie o charakterze obronnym. Wzrasta rozwarstwienie społeczne idące $\mathrm{w}$ parze $\mathrm{z}$ wyodrębnianiem się hierarchii władzy administracyjnej i religijnej będącej w stanie mobilizować i nadzorować prace poddanych na rzecz dynastii czy wojny. Ważnym elementem przemian zrazem jednym z czynników je dynamizujących jest rozpowszechnienie się wyrobów z brązu. Wkroczenie w epokę metalu musi być jednak rozpatrywane jako element rozwoju społecznego i technologicznego miejscowego społeczeństwa neolitycznego, czego świadectwem jest obserwowany stopniowy wzrost złożoności struktur społecznych i praktyk religijnych. Wyroby ceramiczne i z nefrytu często porażają wręcz wyszukanym zdobnictwem i bogactwem form, co świadczy o wysokim smaku artystycznym.

${ }^{27}$ K. C. Chang, The Archaeology of Ancient China, London 1977, s. 85-91. Według najnowszych badan, choć nie do końca jeszcze potwierdzonych, radioweglowych dat, znalezisk ryżu moga przesunać początki neolitu w regionie rzeki Yangzijiang nawet o 3500 lat, czyli do 11500 lat temu. Spencer P M. Harrington, $E$ Archaeological Institute d America http.//www archaeology orgionlinełnews/rice htm

${ }^{28}$ K. C. Chang, The Early Chinese Ciuilisation: Anthropological perspectives, Cambridge 1976.
Pierwsze znamiona chalkolitu, czyli okresu przejściowego pomiędzy epoką kamienia i brązu, sporadycznie pojawiają się już w połowie $\mathrm{V}$ tysiąclecia p.n.e. Liczba znalezisk wzrasta na stanowiskach z III tysiąclecia, głównie na północnym zachodzie, ale również w Henanie i Shantungu. Są to głównie prymitywne noże, szydła i wiertła wykonane z miedzi i brązu. Dyskusyjną pozostaje kwestia genezy metalurgii w Chinach. Konstrukcja form i rdzeni glinianych stosowanych do wytopu brązów, jaka gwałtownie się rozwinęła w II tysiącleciu p.n.e. jest świadectwem szybkiej adaptacji, jeśli nie miejscowego rozwoju opartego na wysoko rozwiniętych technologiach wysokotemperaturowych pieców ceramicznych. Świadectwem miejscowego rozwoju jest również ciągłość stylistyczna i estetyczna naczyń brązowych nawiązujących wyraźnie do wcześniejszych form ceramiki. Są one zatem przede wszystkim kontynuacją tej dawniejszej tradycji, podczas gdy nowe zupełnie wzorce występują rzadziej.

Pierwszą na pały legendarną dynastią chińską jest dynastia Xia, datowana na okres XXI-XVI wieku p.n.e. Kroniki wymieniają imiona siedemnastu królów te dynastii. Jednak dopiero z okresu następnej dynastii Shang pochodzą pierwsze świadectwa pisane, przez co, mimo bardzo intensywnych poszukiwań, trudno jest definitywnie przypisać określone stanowiska do dynastii Xia. Za jedną ze stolic Xia uważa się silnie ufortyfikowane stanowisko późno neolityczne z Wang Zhenggang (wzgórze królewskiego miasta?) w Henanie, czy Deng Xiafeng w Xia Xien, południowe Shansi. Problemy z identyfikacją pogłębiane są możliwością współwystępowania stanowisk dynastii Xia i Shang. Trudności te nie zmieniaja jednak faktu, że przed pojawieniem sie już w pełni historycznej dynastii Shang (XVI-XI w. p.n.e.) mamy do czynienia z wysoko rozwiniętymi społecznościami, którym do stworzenia cywilizacji brakowało tylko jednego elementu, choć występującego już w formie zalążkowej - pisma ${ }^{29}$. Dodać trzeba, że w Chinach południowo-zachodnich, w prowincjach Yunnan i Sichuan rozwinęły się, niezależnie od północnych, ośrodki kultury brązu ze wspaniałymi dziełami, i jak też można mniemać, centra wczesnopaństwowe. Tak więc Chiny starożytne pokrywa istna sieć wspaniałych kultur neolitycznych o złożonych związkach wzajemnych, a później i centrów kultury brązu związanych ze wczesnymi tworami państwowymi.

$\mathrm{Z}$ punktu widzenia podstaw dla rozwoju cywilizacji istotnym jest nie tylko fakt istnienia $w$ Chinach niezależnego centrum rewolucji neolitycznej, ale również cechy tamtejszego rolnictwa. Tym, co umożliwiło pokonanie kolejnego progu kulturowego, nie jest jednak fakt oparcia rolnictwa na irygacji, jak to sugeruje K. Wittfogel, lecz oparcie gospodarki na

\footnotetext{
${ }^{29}$ K. C. Chang, Shang Ciuilisation, London, 1980, s. 348-355.
} 
uprawach zbóż, takich jak proso i ryż. Najważniejszą cechą takiego typu rolnictwa, z punktu widzenia dalszego ich rozwoju, jest możliwość łatwego transportu, gromadzenia i przechowywania nadwyżek żywności.

Rewolucja neolityczna stworzyła, w zależności od warunków środowiskowych trzy typy gospodarki - pasterstwo, rolnictwo oparte na roślinach korzeniowych oraz bulwiastych i rolnictwo oparte na uprawie zbóż. Nomadyczne pasterstwo wytworzyło swoją własna linię rozwojową. Jej zwieńczeniem była „cywilizacja" wielkiego stepu. Cudzysłów przy słowie cywilizacja jest tu użyty tylko dlatego, że brak w niej jednego elementu — właśnie miasta — do spełnienia wymogów dekalogu Childa. Z kolei rolnictwo kopieniacze w klimacie tropikalnym, mimo równie starożytnego rodowodu jak to powstałe na Bliskim Wschodzie, napotkało poważne przeszkody uniemożliwiające, mimo wielu osiągnięć technologicznych, przejście od społeczności plemiennych do struktur państwowych. Przykładem sa społeczności neolityczne na Nowej Gwinei gdzie znaleziono ślady ogrodów datowane na okres 7000 lat p.n.e., a poświadczona obecność systemów irygacyjnych sięga $\mathrm{V}$ tysiąclecia p.n.e. Mimo tego, oraz istniejących kontaktów z Azją Południowa Wschodnią, neolit przetrwał tam w prawie niezmienionej formie do połowy $\mathrm{XX}$ wieku ${ }^{30}$. Podstawową barierą uniemożliwiającą dalszy rozwój była niemożność gromadzenia i łatwego transportu nadwyżek żywności i przechowywania ich przez dłuższy okres czasu. Rośliny bulwiaste $\mathrm{w}$ warunkach tropikalnych można było magazynować stosunkowo krótko, a ponadto nie był możliwy transport na dalsze odległości. Tego rodzaju bariery nie występowały w rolnictwie Chin. Już w neolicie widoczne są efekty powstawania nadwyżek żywności w postaci zróżnicowania społecznego i co za tym idzie tworzenia się zrębów społeczeństwa klasowego.

Jak widać, początki cywilizacji w Chinach sięgają daleko w przeszłość. Istotnymi elementami procesu jej formowania było istnienie rozległego kompleksu kultur neolitycznych, z wieloma ośrodkami lokalnymi, rozwijających zarówno na północ jak i południe od Yangzijiang oraz oparcie rolnictwa na ryżu (południe) i prosie (północ) oraz hodowli przede wszystkim świni i psów. Te ostatnie zwierzęta zachowały do dziś swoje znaczenie jako przysmaki kuchn chińskiej, a sa podstawy sądzić, że dawniej miały one również duże znaczenie obrzędowe. Seung-Og Kim twierdzi, że w szczególności świnie, których kości są najczęstszym znaleziskiem szczątków zwierzęcych z okresu neolitu w Chinach, były nie tylko ilu-

${ }^{30}$ J. E. Pfeiffer, The Emergenee of Society, New York, 1977, ss. 302-307. Por. również D. K. Feil, Tehe euolution of Highland Papua New Guinea societes, Cambridge 1987, Cambridge University Press. stracją zróżnicowania społecznego widocznego $\mathrm{w}$ pochówkach, ale również elementem zdobywania prestiżu społecznego ${ }^{31}$. Do dziś świnia zachowała swoje znaczenie kultowe, odgrywa dużą rolę w rozmaitych obrzędach, w tym niezmiernie ważnych w tym kraju - pogrzebowych. Dodać warto, że znak chiński oznaczający rodzinę i dom — jia składa się z dwóch elementów obrazujących świnię pod dachem. Zwierzę to zajmuje ważne miejsce również w chińskiej mitologii i folklorze ${ }^{32}$.

Podsumowując można stwierdzić, że powstanie cywilizacji chińskiej dokonało się na bazie miejscowych kultur neolitycznych. Przebieg tego procesu mającego wszelkie cechy oryginalności i miejscowej specyfiki przebiega jednak według podobnych schematów rozwoju społecznego, jak to miało miejsce w przypadku Egiptu, Mezopotamii czy Indii.

Dalszy rozwój cywilizacji chińskiej nie daje podstaw do uprawomocnienia sądów o „immobilności", czy „konserwatywnym zastoju". W gruncie rzeczy dopiero wielkie najazdy półkoczowniczych i koczowniczych ludów z północy, jakie spustoszyły kraj, zahamowały ten dynamiczny rozwój umożliwiając jednocześnie rozprzestrzenienie się wielu jakże istotnych dla dynamicznego rozwoju cywilizacji zachodniej wynalazków, jak chociażby kompas i proch Cywilizacja Chin aż do XVIII w. była jedna z przodujących w świecie, jeśl nie wręcz najwyżej rozwiniętą. Dopiero rewolucja przemysłowa i naukowotechniczna w Europie w końcu XVIII i w XIX w., jak też rewolucje polityczne ideologiczne, jakie tam nastąpiły, zapewniły Zachodowi dominację nad całą reszta świata, w tym i nad Chinami. Przyczyny zapóźnienia w tym czasie nie tylko Chin wobec Zachodu nie mogą być zatem upatrywane jedynie w mechanizmach władzy „,despotycznej" czy ,azjatyckiej" tak odmiennych państw jak Indie, Turcja czy Chiny.

${ }^{31}$ Seung-Og Kim, "Burials, pigs, and political prestige in Neolitic China", Current Anthropology, Vol. 35, Na 2, April 1994, s. 119-141.

22 Ka Bo Tsang, „Pig tales, popular trditions mirrors a people's ambivalent feeligs about swine", Archeology, March/April 1996 w the Archaeological Institute of America h ttp://ww w. archaeo logy.o rglo nline/n ews/pigs.html 